\title{
Pituitary adenomas producing growth hormone in acromegalic patients
}

\author{
LESLEY A SMALLMAN, PJS DUNN, RC CURRAN, DR LONDON* \\ From the Department of Pathology, Medical School, University of Birmingham, Birmingham B15 2TJ and \\ ${ }^{*}$ Queen Elizabeth Hospital, Birmingham B15 2TH
}

SUMMARY Growth hormone was shown in histological sections of 25 pituitary adenomas from acromegalic patients by means of the unlabelled peroxidase-antiperoxidase (PAP) technique. On the basis of the numbers of cytoplasmic granules, the cells of the adenomas were of two types: densely granulated and sparsely granulated. The densely granulated cells had abundant cytoplasm containing numerous granules, whereas the sparsely granulated cells had little cytoplasm with scanty granules. Depending on the predominant cell type the adenomas were also classified as densely granulated or sparsely granulated: 21 of the 25 adenomas $(84 \%)$ were densely granulated and four $(16 \%)$ sparsely granulated. There was some variation, however, in the relative numbers of the two types of cell from one part of an adenoma to another, a feature consistent with one type of cell in different phases of activity. There was no significant difference in mean serum growth hormone concentrations between the two groups, and granularity of the adenomas in histological sections did not therefore correlate with secretory activity.

Nine adenomas showed extrasellar extension. The mean serum growth hormone concentration in these cases was lower than the mean of the adenomas confined to the sella turcica. Thus the size of the tumour did not correlate with the serum growth hormone concentration. Three of the four adenomas in the sparsely granulated group showed extrasellar extension, compared with 6 of 21 classified as densely granulated. This suggests that sparsely granulated adenomas have a more aggressive pattern of behaviour, but histological evidence for this was lacking.

Growth hormone has an affinity for acid dyes, and in histological sections cells containing growth hormone stored in granules in cell cytoplasm should be acidophil. In accordance with this is the fact that acromegaly caused by increased concentrations of serum growth hormone is usually associated with an acidophil adenoma of the pituitary. ${ }^{1}$ Variation in the strength of acidophil staining of cytoplasm would be expected to indicate differences in the hormone content of cells, but in some cases of acromegaly the pituitary adenomas have consisted of a mixture of both acidophil and chromophobe cells, or even mainly of chromophobes. ${ }^{2-6}$ Moreover, other conditions are associated with acidophilia of the cells of an adenoma..$^{5-9}$ The term chromophobe adenoma was introduced to describe pituitary tumours which consisted of cells lacking granules (acidophil or basophil), but McCormick and Halmi ${ }^{10}$ showed that in thin paraffin sections of Susa fixed material stained by special techniques a few cytoplasmic granules could be identified in all chromophobe adenomas.

Assessment of the hormone content of a pituitary adenoma by conventional histological methods is therefore difficult. Peptide hormones retain their antigenicity after fixation and embedding in paraffin wax, however, and it is possible to show the presence of growth hormone in paraffin sections of formalin fixed and routinely processed pituitary tissue by immunohistochemical methods. ${ }^{11}{ }^{12}$ In this study 25 pituitary adenomas from acromegalic patients were examined for the presence of growth hormone by means of the unlabelled peroxidaseantiperoxidase technique using a highly specific antiserum to human growth hormone. The results are considered in the light of the clinical and biochemical findings.

\section{Material and methods}

Twenty five pituitary adenomas from acromegalic 
Pituitary adenomas producing growth hormone in acromegalic patients

Table 1 Clinical summary, hormone concentrations, and immunohistochemical results in acromegalic patients

\begin{tabular}{|c|c|c|c|c|c|c|c|c|}
\hline $\begin{array}{l}\text { Case } \\
\text { no }\end{array}$ & Sex & $\begin{array}{l}\text { Age at } \\
\text { presentation (yr) }\end{array}$ & $\begin{array}{l}\text { Duration of } \\
\text { symptoms (yr) }\end{array}$ & $\begin{array}{l}\text { Local tumour } \\
\text { extension }\end{array}$ & $\begin{array}{l}\text { Serum growth } \\
\text { hormone concentration } \\
\text { before operation or } \\
\text { DXRT (mU/l) }\end{array}$ & Operation & $D X R T$ & Immunostain \\
\hline $\begin{array}{l}1 \\
2\end{array}$ & $\begin{array}{l}\mathbf{M} \\
\mathbf{M}\end{array}$ & $\begin{array}{l}66 \\
54\end{array}$ & $\begin{array}{r}1 \\
10\end{array}$ & $\begin{array}{l}\text { Suprasellar } \\
\text { Sphenoidal } \\
\text { Sinus }\end{array}$ & $\begin{array}{l}80 \\
88\end{array}$ & $\begin{array}{l}\text { T-S } \\
\text { T-S }\end{array}$ & & $\begin{array}{l}\text { SG } \\
\text { SG }\end{array}$ \\
\hline $\begin{array}{c}3 \\
4^{*} \\
5 \\
6 \\
7 \\
8 \\
9 \\
10^{*} \\
11 \\
12 \\
13^{*}\end{array}$ & $\begin{array}{l}\mathbf{M} \\
\mathbf{M} \\
\mathbf{F} \\
\mathbf{M} \\
\mathbf{F} \\
\mathbf{M} \\
\mathbf{M} \\
\mathbf{M} \\
\mathbf{M} \\
\mathbf{F} \\
\mathbf{M}\end{array}$ & $\begin{array}{l}33 \\
42 \\
39 \\
28 \\
52 \\
45 \\
38 \\
52 \\
45 \\
21 \\
50\end{array}$ & $\begin{array}{c}10 \\
3 \\
5 \\
5 \\
1 \\
10 \\
3 \mathrm{mo} \\
6 \mathrm{mo} \\
5 \\
3 \\
6 \mathrm{mo}\end{array}$ & $\begin{array}{l}\text { Suprasellar } \\
\text { Suprasellar } \\
\text { Sphenoidal } \\
\text { Sinus }\end{array}$ & $\begin{array}{c}34 \cdot 5 \\
131 \cdot 5 \\
123 \\
222 \\
94 \\
57 \\
52 \\
33 \\
58 \\
42 \\
30\end{array}$ & $\begin{array}{l}\text { T-S } \\
\text { T-S } \\
\text { T-S } \\
\text { T-S } \\
\text { T-S } \\
\text { T-S } \\
\text { T-S } \\
\text { T-S } \\
\text { T-S } \\
\text { T-S } \\
\text { T-S }\end{array}$ & DXRT & $\begin{array}{l}\text { SG } \\
\text { SG } \\
\text { DG } \\
\text { DG } \\
\text { DG } \\
\text { DG } \\
\text { DG } \\
\text { DG } \\
\text { DG } \\
\text { DG } \\
\text { DG }\end{array}$ \\
\hline $\begin{array}{l}14 \\
15 \\
16 \\
17 \\
18 \\
19 \\
20 \\
21 \\
22 \\
23 \\
24^{*} \\
25\end{array}$ & $\begin{array}{l}\mathbf{F} \\
\mathbf{M} \\
\mathbf{F} \\
\mathbf{F} \\
\mathbf{M} \\
\mathbf{F} \\
\mathbf{F} \\
\mathbf{F} \\
\mathbf{F} \\
\mathbf{F} \\
\mathbf{M} \\
\mathbf{M}\end{array}$ & $\begin{array}{l}60 \\
35 \\
57 \\
33 \\
44 \\
58 \\
41 \\
30 \\
57 \\
55 \\
38 \\
56\end{array}$ & $\begin{array}{r}5 \\
2 \\
23 \\
4 \\
8 \\
8 \\
4 \\
5 \\
8 \\
2 \\
3 \\
17\end{array}$ & $\begin{array}{l}\text { Suprasellar } \\
\text { Suprasellar }\end{array}$ & $\begin{array}{l}38 \\
36 \cdot 5 \\
23 \cdot 5 \\
25 \\
35 \cdot 5 \\
10 \\
119 \\
155 \\
36 \cdot 5 \\
104 \\
10 \\
500\end{array}$ & $\begin{array}{l}\text { T-S } \\
\text { T-S } \\
\text { T-S } \\
\text { T-S } \\
\text { T-S } \\
\text { T-S } \\
\text { T-S } \\
\text { C } \\
\text { Necropsy } \\
\text { T-S } \\
\text { T-S } \\
\text { Necropsy }\end{array}$ & $\begin{array}{l}\text { DXRT } \\
\text { DXRT }\end{array}$ & $\begin{array}{l}\text { DG } \\
\text { DG } \\
\text { DG } \\
\text { DG } \\
\text { DG } \\
\text { DG } \\
\text { DG } \\
\text { DG } \\
\text { DG } \\
\text { DG } \\
\text { DG } \\
\text { DG }\end{array}$ \\
\hline
\end{tabular}

${ }^{*}$ Preoperative bromocriptine treatment.

T-S = Trans-sphenoidal; C $=$ cranial; DXRT $=$ deep $x$ ray treatment; $S G=$ sparsely granulated; DG $=$ densely granulated.

patients were studied (Table 1). The diagnosis was based on the classic physical changes and a raised serum growth hormone concentration during a glucose tolerance test as measured by radioimmunoassay. Patients were excluded when a fasting, resting unstressed basal concentration or at least one result during an oral glucose tolerance test was $5 \mathrm{mU} / \mathrm{l}$ or less. Four patients (cases 4, 10,13, and 24) received preoperative bromocriptine treatment. Twenty two adenomas were obtained by the trans-sphenoidal and one by the frontal approach. In case 9 the pituitary adenoma was approached by the transsphenoidal route, but for technical reasons this procedure was abandoned and radiotherapy was given. Tissue was obtained, however, for a histological diagnosis. Two patients (cases 22 and 25) were treated by radiotherapy and their pituitaries were removed at necropsy. Although as a rule the tissue available represented only part of each adenoma, the amount seemed sufficient to be representative of the whole tumour.

\section{FIXATION AND PROCESSING OF TISSUES}

All but one of the tissue specimens were fixed for $24 \mathrm{~h}$ in formol saline-sucrose: $4 \%$ formaldehyde (prepared from $40 \%$ formalin BP) in $0.85 \%$ sodium chloride solution with $1.5 \%$ sucrose. The other specimen, a pituitary obtained at necropsy, was fixed for $24 \mathrm{~h}$ in Bouin's fluid.

The tissues were either hand processed and dehydrated in industrial methylated spirit, cleared in xylene, and impregnated in paraffin wax; or they were processed on an automatic processor and dehydrated in industrial methylated spirit, cleared in chloroform, and impregnated in paraffin wax.

\section{TISSUE SECTIONS AND HISTOLOGY}

In each case 10 serial sections $4 \mu \mathrm{m}$ thick were cut and all sections brought to water through alcohol. Sections 1, 2, 4, 6, and 8 were used for histology: section 1 was stained by Harris's haematoxylin and eosin; sections 2 and 6 by Slidder's method, ${ }^{13}$ and sections 4 and 8 by Brookes's method. ${ }^{14}$ Sections 3 , $5,7,9$, and 10 were used for the PAP technique. Slidder's method stains the cytoplasm of acidophil cells orange and that of the basophils green. Brookes's method differentiates between cells containing growth hormone (orange) and cells containing prolactin (red), with the basophils staining green.

IMMUNOHISTOCHEMICAL PROCEDURE

Growth hormone was shown in sections 3, 5, and 7 by the PAP technique. ${ }^{15}$ All steps were carried out 
at room temperature $\left(20^{\circ} \mathrm{C}\right)$. In preliminary tests untrypsinised sections showed little immunoreactivity, and so before immunohistochemistry the sections were trypsinised by incubation at $37^{\circ} \mathrm{C}$ in Tris saline buffer ( $\mathrm{pH} 7.8)$ containing $0.1 \%$ trypsin and $0.1 \%$ calcium chloride. ${ }^{16}$ Maximum reactivity was found after an incubation period of $20 \mathrm{~min}$.

Rabbit antihuman growth hormone antiserum (Miles Laboratories Limited, Stoke Poges, Slough, England; Lot No 524H; Code No 61-376) was used. It was evaluated by a double antibody radioimmunoassay procedure using $50 \mathrm{pg} /$ tube of ${ }^{125}$ I-human growth hormone with a specific activity of about $80 \mu \mathrm{Ci} / \mathrm{ug}$. The crossreactivity with prolactin (NIH) P-S-8 Ovine was less than $0.001 \%$. A range of titres was used to find the optimum dilution for the antihuman growth hormone antiserum. This varied between $1 / 4000$ and $1 / 8000$.

Sections 9 and 10 were used as controls. Tris saline buffer $(\mathrm{pH} \mathrm{7.6)}$ was used in place of the specific antiserum, the swine antirabbit immunoglobulin antiserum, or the PAP complex. The reaction was also specifically blocked by the addition of an equal volume of a range of dilution (1/50 to $1 / 1000000$ ) of human growth hormone to the antihuman growth hormone antiserum up to a titre of $1 / 4000$. The growth hormone had an activity of 2.89 IU $/ \mathrm{mg}$ and contained $0.1 \%(24.9 \mathrm{mU} / \mathrm{mg})$ contamination with prolactin.

\section{CLINICAL DATA}

The following clinical and biochemical information was available in each case: sex, age at presentation, duration of symptoms, local tumour extension as diagnosed on $x$ ray examination or by computed tomography, and serum growth hormone concentration before surgery or radiotherapy.

\section{Results}

Histologically, the pituitary adenomas were highly cellular. In seven adenomas the cells formed a diffuse pattern with no characteristic architectural arrangement: the connective tissue stroma was scanty and contained only a few small blood vessels (Fig. 1a). In the other 17 cases the cells were arranged in a trabecular pattern with groups, strands, and cords of cells separated by delicate vascular connective tissue septa (Fig. 2 and 3a). In only three of the 25 cases was vascularity of the tumour a prominent feature. A papillary arrangement of the cells was not seen in any specimen. Cell boundaries were often indistinct. The cytoplasm of many of the cells stained deeply with eosin, but the intensity varied widely, the large cells with their more abundant cytoplasm being notably more eosinophil than the smaller cells. The eosinophil cytoplasm also generally showed distinct granularity. In most cells, but particularly in the larger cells, there was a poorly stained area adjacent to the nucleus. This was present even in the largest and most densely stained cells (Fig. 1a) and was presumably the "fibrous globular body" seen in micrographs of the cells in adenomas which secrete growth hormone. ${ }^{17}$ Irrespective of their cytoplasmic content the cells had large pleomorphic nuclei with prominent nucleoli. Occasional cells had giant nuclei or multiple nuclei, but mitotic figures were rare.

The PAP technique showed very small granules of brown reaction product within the cytoplasm in a large proportion of the tumour cells in all adenomas. On the basis of the numbers of cytoplasmic granules, the cells were classified as either densely granulated or sparsely granulated: the densely granulated cells had abundant cytoplasm in which there were large numbers of granules (Fig. 1b) and the sparsely granulated cells had only a thin rim of perinuclear cytoplasm which contained scanty granules (Fig. $3 b)$. The area adjacent to the nucleus, which was weakly eosinophil in haematoxylin and eosin preparations, contained very few granules (Fig. 1b).

Depending on the cell type the adenomas themselves were categorised as either densely granulated or sparsely granulated. Of the 25 adenomas studied, $21(84 \%)$ were densely granulated and four $(16 \%)$ were sparsely granulated (Table 1). The distribution of the two types of cells throughout the tissue was irregular but the method gave reproducible results: two observers (LAS and PJSD), without prior knowledge of the clinical data, independently allocated the same cases to each of the two groups.

Cytoplasmic granularity was also shown well by the methods of Slidder ${ }^{13}$ and Brookes, ${ }^{14}$ the latter method being particularly effective in this respect. The use of serial sections showed good correlation between the results with these methods and the immunohistochemical technique: the number of cells containing cytoplasmic granules and the intensity of cytoplasmic granularity of individual cells corresponded closely in adjacent sections subjected to all three methods.

Three of the four patients who received preoperative bromocriptine treatment had densely granulated adenomas (Table 1).

The four patients in the sparsely granulated group were male, whereas in the 21 patients in the densely granulated group the sex ratio was roughly equal. There was no significant difference in mean age at presentation, duration of symptoms, or preoperative serum growth hormone concentration between the two groups (Tables 1 and 2).

Nine adenomas showed extrasellar extension on 


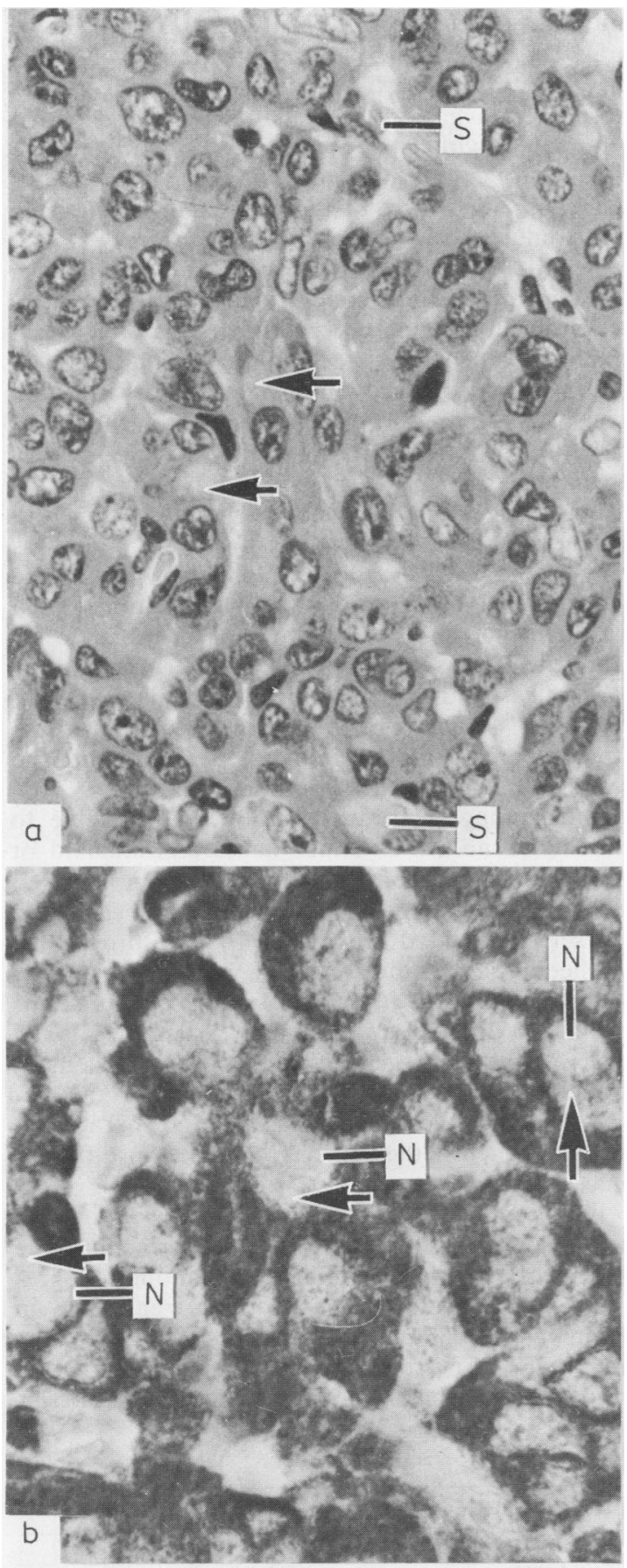

Fig. 1 Densely granulated adenoma. (a) The tumour cells are arranged in a diffuse pattern and have large pleomorphic nuclei with prominent nucleoli. There are no mitotic figures. Cytoplasm is abundant and well stained. In a few cells, however, there is a paler staining area (arrow) adjacent to the nucleus. Stroma $(S)$ is scanty and contains only a few small blood vessels. Haematoxylin and eosin $\times 630$. (b) The cytoplasm of all the cells contains large numbers of very small granules reacting positively for growth hormone. In each cell, however, the area (arrow) adjacent to the nucleus $(N)$ (see Fig. 1a) contains only a few granules. PAP technique for growth hormone. The nuclei have not been counterstained. Original magnification $\times 1180$. 


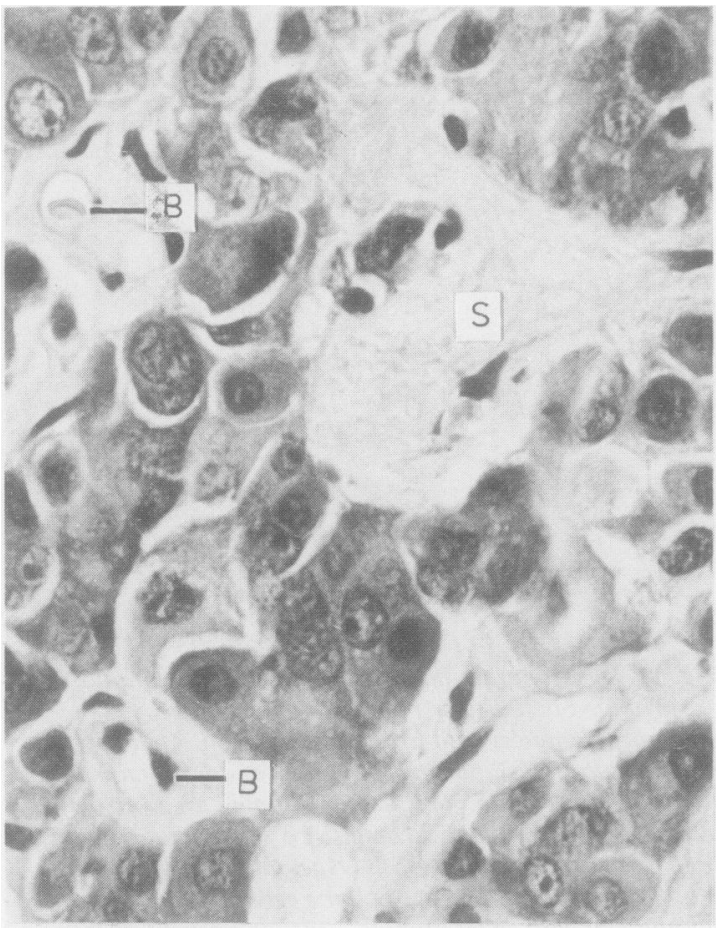

Fig. 2 Densely granulated adenoma. The tumour cells form a trabecular pattern, with the groups and strands of cells separated by abundant pale fibrous stroma $(S)$ rich in small blood vessels $(B)$. The cells have abundant well stained cytoplasm. The nuclei are more pleomorphic than in the adenoma shown in Fig. Ia and a few giant forms are present. There are no mitoses. Haematoxylin and eosin $\times 630$.

$x$ ray examination or computed tomography: three were sparsely granulated and six were densely granulated (Table 1). Their mean serum growth hormone concentration was lower $(78.44 \mathrm{mU} / \mathrm{l})$ than the mean of the adenomas confined to the sella turcica $(89.5 \mathrm{mU} / \mathrm{l})$.

\section{Discussion}

Until recently most investigators have used morphology, as determined by light and electron mic- roscopy, to characterise the cells of adenomas of the anterior pituitary. These methods have shown granules within the cells, and on the basis of their cytoplasmic granularity adenomas producing growth hormone have been classified as either densely granulated, with most of the cells containing large numbers of cytoplasmic granules, or sparsely granulated, in which most of the cells contain relatively few granules.

Recently, it has been shown that many antigens, including peptide hormones, retain their antigenicity after fixation and processing to paraffin wax. Immunohistochemical techniques can therefore be used for detecting growth hormone in paraffin sections. ${ }^{112}$ The present study was based on the use of paraffin sections of routinely processed pituitary adenomas from acromegalic patients, using the PAP technique for growth hormone. The sections proved unreactive or weakly reactive, however, and it was only when they had been treated with trypsin before the application of antihuman growth hormone that a satisfactory reaction was obtained. Trypsin treatment of sections was not used in other immunohistochemical studies of adenomas producing growth hormone, ${ }^{18}$ and since the tissues used in these studies were also formalin fixed, it is likely that the results obtained were suboptimal.

Our findings confirmed that it was possible to classify adenomas as either densely granulated or sparsely granulated, the densely granulated adenomas $(84 \%)$ considerably out numbering the sparsely granulated lesions $(16 \%)$. The prevalence of the densely granulated type is more than that found by Young et $a l^{3}$ and Trouillas et $a l^{19}$ but comparable to that of Lewis and Van Noorden. ${ }^{4}$ Use of such a method of classification rests on densely granulated and sparsely granulated cells being distinct types of cell with specific and fixed characteristics and not just the same type of cell in different phases of activity.

In this context it is important that three of the four patients in our series who received bromocriptine treatment had densely granulated adenomas. A previous report on bromocriptine treatment in acromegalic patients ${ }^{20}$ also indicated that the tumours were more granulated after treatment with bromocriptine than control pituitaries. Bromocrip-

Table 2 Analysis of the clinical data in the two groups of pituitary adenomas

\begin{tabular}{lllc}
\hline & All pituitary adenomas & Densely granulated group & Sparsely granulated group \\
\hline No of adenomas & 25 & 21 & 4 \\
Sex ratio & $14 \mathrm{M}: 11 \mathrm{~F}$ & $10 \mathrm{M}: 11 \mathrm{~F}$ & $4 \mathrm{M}: 0 \mathrm{~F}$ \\
Mean age at presentation $(\mathrm{yr})$ & $45 \cdot 16$ & $44 \cdot 48$ & $48 \cdot 75$ \\
Mean duration of symptoms $(\mathrm{yr})$ & $5 \cdot 73$ & $5 \cdot 68$ & $6 \cdot 0$ \\
$\begin{array}{l}\text { Mean serum growth hormone } \\
\quad \text { concentration before treatment }(\mathrm{mU} / \mathrm{l})\end{array}$ & $87 \cdot 56$ & $88 \cdot 33$ & $83 \cdot 50$ \\
\hline
\end{tabular}




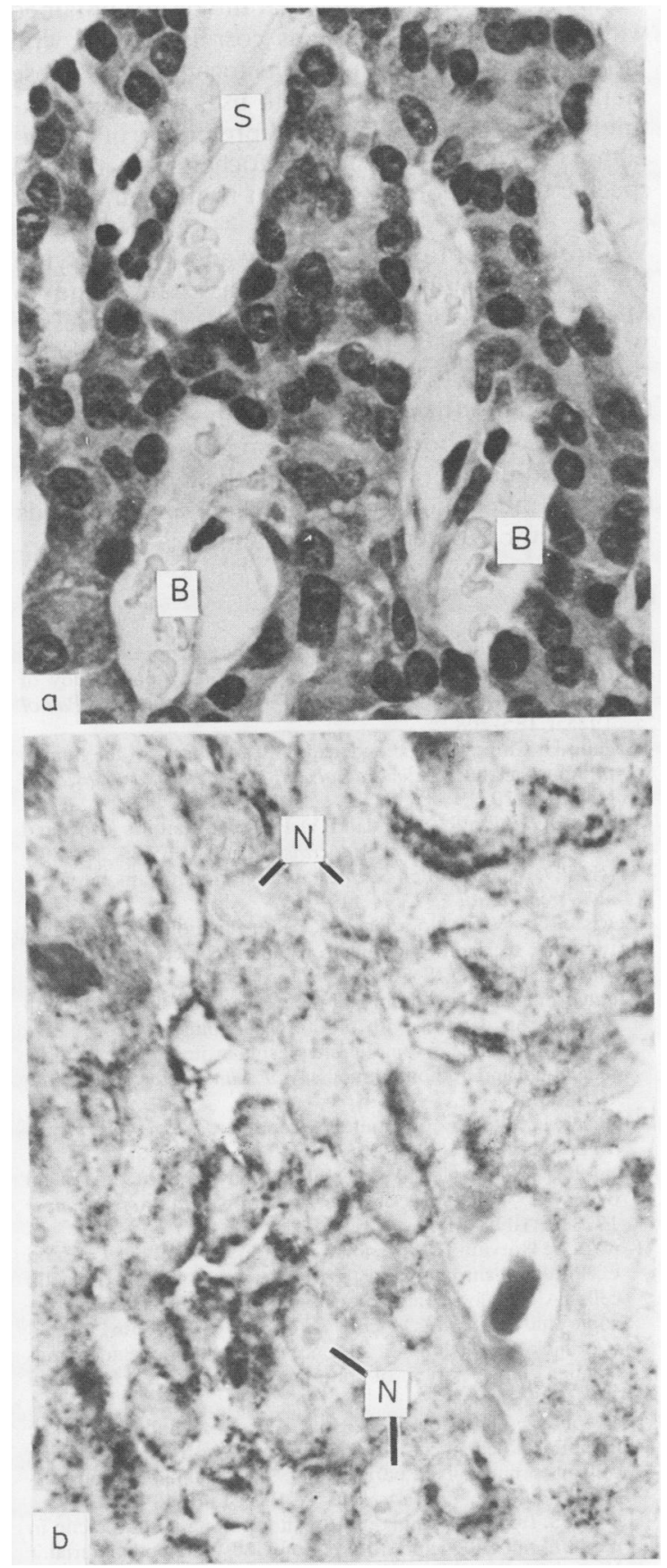

Fig. 3 Sparsely granulated adenoma. (a) The structure is trabecular, the tumour cells forming cords separated by stroma $(S)$ rich in small blood vessels $(B)$. The cytoplasm in each cell is less abundant than in a densely granulated adenoma (Fig. 2). The nuclei show moderate pleomorphism. Haematoxylin and eosin $\times 630$. (b) The scanty cytoplasm in each cell contains only a small number of positively reacting granules. $N=$ nucleus. $P A P$ technique for growth hormone. The nuclei have not been counterstained. $\times 1180$. 
tine blocks release (exocytosis) but not synthesis of the hormone and these findings suggest that the granularity of individual cells of the adenomas can be changed with treatment. Classifying adenomas into densely granulated and sparsely granulated would therefore appear to be of limited value.

Electron microscopy has shown that the cells in sparsely granulated adenomas have an expanded rough endoplasmic reticulum and Golgi complex, features of active production and secretion of hormone, whereas in densely granulated adenomas the rough endoplasmic reticulum and Golgi complex are less prominent, an appearance more typical of cells in the storage phase. ${ }^{2451821}$ These results suggest that patients with densely granulated adenomas are storing the hormone and should tend to have lower serum concentrations of growth hormone than those with sparsely granulated adenomas. The degree of granularity of the adenomas gave no indication of preoperative secretory activity, however, there being no significant difference in preoperative serum growth hormone concentrations between sparsely granulated and densely granulated adenomas. Previous attempts by others to correlate the granularity of a tumour with the preoperative growth hormone concentrations have also been inconclusive: thus while Lewis and Van Noorden ${ }^{4}$ and Niewenhuyzen Kruseman $e t$ al ${ }^{18}$ reported serum concentrations on average three times higher in sparsely granulated adenomas, others have been unable to confirm this observation. ${ }^{919}$

Attempts to correlate tumour size and hormone secretion have been equally unrewarding. Although earlier studies showed a direct correlation between tumour size and serum growth hormone concentration, ${ }^{22}$ Trouillas et al ${ }^{19}$ found no correlation between the two; and in our series of cases the nine adenomas which showed extrasellar extension and presumably were large tumours had a mean serum growth hormone concentration lower than that of those adenomas confined to the sella turcica.

On the basis that granularity might vary inversely with the degree of differentiation, it has also been proposed $^{318}$ that sparsely granulated adenomas show more aggressive local growth as shown by extrasellar extension on $x$ ray film or computed tomogram. Three of the four sparsely granulated adenomas in the present study showed extrasellar extension compared with six of the 21 tumours classified as densely granulated, but these numbers are small and the evidence can be regarded as only suggestive. The reason for this difference in behaviour was not apparent in other histological features of the tumours, although correlation between the histological structure of endocrine tumours and their biological behaviour generally tends to be poor.

Finally, it is worth noting that the results obtained with traditional dye methods correlated well with those obtained with immunohistochemistry. These methods are cheap and easy to use, and their continued use seems fully justified, preferably in combination with an immunohistochemical method specific for the hormone present in the cell.

We are grateful to $\mathbf{M r} \mathbf{J}$ Gregory and Miss P Byrne for technical and photographic assistance and to Miss A Wright for typing the manuscript. Professor WR Butt and Dr SS Lynch, Department of Clinical Endocrinology, Birmingham and Midland Hospital for Women, Birmingham, kindly donated the human growth hormone. Serum growth hormone concentrations were measured at the Department of Clinical Endocrinology, Birmingham and Midlands Hospital for Women, Birmingham.

\section{References}

' Bailey P, Davidoff LM. Concerning the microscopic structure of the hypophysis cerebri in acromegaly (based on a study of tissue removed at operation from 35 patients). Am J Pathol 1925;1:185-208.

${ }^{2}$ Schelin U. Chromophobe and acidophil adenomas of the human pituitary gland. Acta Pathol Microbiol Scand 1962;158 (suppl):1-20.

${ }^{3}$ Young DG, Bahn RC, Randall RV. Pituitary tumours associated with acromegaly. J Clin Endocrinol Metab 1965;25:249-89.

${ }^{4}$ Lewis PD, Van Noorden S. Pituitary abnormalities in acromegaly. Arch Pathol 1972;94:119-26.

s Lewis PD, Van Noorden S. "Non-functioning" pituitary tumours. A light and electron microscopical study. Arch Pathol 1974;97:178-82.

- Zimmerman EA, Defendini R, Frantz AG. Prolactin and growth hormone in patients with pituitary adenomas. A correlative study of hormone in tumour and plasma by immunoperoxidase technique and radioimmunoassay. J Clin Endocrinol Metab 1974; 38: 577-85.

' Doniach I. Cytology of pituitary adenomas. J Roy Coll Physicians Lond 1972;6:299-306.

${ }^{8}$ Landolt AM, Oswald KW. Histology and ultrastructure of an oncocytic adenoma of the anterior pituitary. Cancer 1973;31:1099-105.

${ }^{9}$ Kovacs K, Horvath E, Corenblum B, Sirek AMT, Penz G, Ezrin C. Pituitary chromophobe adenomas consisting of prolactin cells. A histologic, immunocytological and electron microscopic study. Virchows Arch [Pathol Anat] 1975;366:113-23.

${ }^{10}$ McCormick WF, Halmi NS. Absence of chromophobe adenomas from a large series of pituitary tumours. Arch Pathol 1971;92:231-8.

" Niewenhuyzen Kruseman AC, Bots G Th AM, Lindeman J. The immunohistochemical identification of hormone-producing cells in formalin-fixed paraffin embedded human pituitary tissue. J Pathology and Bacteriology 1975;117:163-7.

12 Halmi NS. Immunostaining of growth hormone and prolactin in paraffin-embedded and stored or previously stained material. $J$ Histochem Cytochem 1978;26:486-95.

${ }^{13}$ Slidder W. The OFG and Br AB-OFG methods for staining the adenohypophysis. J Pathology and Bacteriology 1961;82: 532-4.

${ }^{14}$ Brookes LD. A stain for differentiating two types of acidophil cells in the rat pituitary. Stain Technol 1968;43:42-3. 
15 Curran RC, Gregory J. Demonstration of immunoglobulin in cryostat and paraffin sections of human tonsil by immunofluorescence and immunoperoxidase techniques. $J$ Clin Pathol 1978;31:974-83.

${ }^{16}$ Curran RC, Gregory J. The unmasking of antigens in paraffin sections of tissue by trypsin. Experientia 1977;33:1400-1.

17 Schochet SS, McCormick WF, Halmi NS. Acidophil adenomas with intracytoplasmic filamentous aggregates. Arch Pathol 1972;94:16-22.

${ }^{18}$ Niewenhuyzen Kruseman AC, Bots G Th AM, Lindeman J, Schaberg A. Use of immunohistochemical and morphologic methods for the identification of human growth hormoneproducing pituitary adenomas. Cancer 1976;38:1163-70.

19 Trouillas J, Girod C, Lhéritier M, Claustrat B, Dubois MP. Morphological and biochemical relationships in 31 human pituitary adenomas with acromegaly. Virchow Arch [Pathol Anat] 1980;389: $127-42$.
${ }^{20}$ Fanghanel SG, Larraza O, Aranco R, Esquivil R, MartinezCampos A, Valverde RC. Serum growth hormone and ultrastructural studies of adenohypophysial tissue in bromocriptine treated acromegalic patients. Clin Endocrinol 1978;9:289-96.

${ }^{21}$ Saegar W. Licht- und elecktronenoptische Untersuchungen zur sekretorischen Aktivität von Hypophysenadenomen bei Ackromegalie. Virchow Arch [Pathol Anat] 1973;358:343-54.

${ }^{22}$ Wright AD, McLachlan MSF, Doyle FH, Frazer TR. Serum growth hormone level and size of pituitary tumour in untreated acromegaly. $\mathrm{Br}$ Med J 1969;iv:582-4.

Requests for reprints to: Dr Lesley A Smallman, Department of Pathology, The Medical School, Birmingham B15 2TJ, England. 